\title{
28 Resarch Soure \\ Land Management Criteria For Green Building Certification Systems In Turkey
}

Bilge Erdede ( $\nabla$ sevimbilge.kececi@omu.edu.tr)

Tapu ve Kadastro Bölge Müdürlüğü https://orcid.org/0000-0001-7366-3743

Sebahattin Bektaş

Ondokuz Mayis Universitesi Muhendislik Fakultesi

Original article

Keywords: Energy, Sustainability, Green Building, Green Building Certification Systems

Posted Date: September 9th, 2020

DOI: https://doi.org/10.21203/rs.3.rs-63564/v1

License: (9) This work is licensed under a Creative Commons Attribution 4.0 International License. Read Full License 


\section{Abstract}

Background: The energy issue is of great importance for energy dependent countries like Turkey. Some legislative regulations such as the Energy Efficiency Law and the Energy Performance Regulation of Building have recently been made in our country. Although the Energy Performance Certificate for buildings has been put into practice, a national green building certification system is not available yet. The most widely used certification systems in the world are BREEAM (Bre Environmental Assessment Method) and LEED (Leadership in Energy and Environmental Design), which do not produce very realistic results. Therefore, it is essential to establish a national certification system. For this purpose, studies have been started by ÇEDBIKK (the Turkish Green Building Council) and Mimar Sinan Fine Arts University (MSFAU). However, it has not yet been legally validated.

Methods: In this study, a survey was conducted to highlight the importance of the category of land management, one of the criteria of the green building certification systems, and to identify sub-criteria under this title more objectively. Worldwide valid certification systems and parts of the certification systems regarding land management that are tried to be established in Turkey were examined to determine the survey questions and in line with this, a literature review was performed. The experts in Turkey were interviewed to gather ideas and insights. By listing the answers from these experts using the AHP method, the criteria and sub-criteria of land method were determined.

Conclusions: In this study, a green building certification system to be established in our country was discussed under the category of land management to which great importance has been attached, especially by survey engineers, and the criteria under this category has been identified. A survey was conducted to determine these criteria, and the results were examined.The subcriteria of the category of land management were identified, and their weights were calculated. A sample program was written in the Microsoft Visual Studio Net 2013 programming language to determine the scores of buildings according to these weights.

\section{Introduction}

In Europe, in the 18th and 19th centuries, new inventions such as steam-powered machines gave the industry the ability to feed more people from the same amount of land and led to population growth cities and increased job opportunities across different industrial sectors.

Efforts to transform the destruction caused by the Second World War into recovery and growth have been the root cause of uncontrolled expansion. This uncontrolled expansion has also created a waste problem. While these waste accumulation did not create problems in society before, they have grown over time and have reached a level that now threatens the entire world ecosystem.

With the technological development in the late 19th and early 20th centuries, information and communication infrastructure has spread to wide geographical areas. The fact that data and information access have become independent from time and space through mobile communication technologies has 
revealed the extent to which human beings have destroyed the ecosystem. This unfortunate development has mobilized Non-Governmental Organizations (NGOs) on issues such as air pollution, water pollution, soil pollution, and radioactive pollution, and world leaders have made agreements such as the Montreal Protocol, Kyoto Protocol, and Stockholm Convention to raise awareness and develop jointly agreed solutions. Today, environmental sensitivity has increased and eco-friendly ecological buildings called "green buildings" have emerged in the building industry. Green buildings are shaped by designs that aim to use less energy and water and reduce the impact of the materials used on environmental life-cycle. Green buildings have undoubtedly been a critical part of the response to the challenges posed by global warming and climate change reaching a critical level. However the benefits provided by green buildings need to be controlled by a mechanism, and therefore the need for certification systems, which is the focus of this article.

Green buildings are no longer a luxury but a necessity because of their impact on human health and the wider environment. As green buildings need to meet certain standardsto provide benefits in environmental, social, and economic terms, systems of certification systems have emerged to verify whether certain buildings meet green credentials. Certification systems control the parameters in the construction process starting from the design phase of the buildings, and determine the green rate for the buildings by determining scores for each parameter. Different countries use different certification systems. The most widely used certification systems are BREEAM in the UK, LEED in the USA, CASBEE in Japan, and Green Star Certification system in Australia [1, 2, 3]. Countries that do not have their own certification system take the certification systems of other countries and adapt them.

Problems such as global warming, depletion of natural resources and climate change have put countries in a difficult situation of having to address multiple challenges. In this context, green buildings that produce their own energy, have wastewater management, are sustainable, comfortable, and efficient buildings have gained further prominence. Many countries use different green building certification systems to evaluate green buildings. Yet there is no national certification system in Turkey. Therefore, buildings are evaluated using foreign certification systems, and this does not always produce contextrelevant results for Turkey. In this regard, it has become crucial to a create a national certification system for Turkey.

The aim of this study is to identify the criteria under the title 'land management', being one of the most important sub-criteria of green building certification systems, which has a crucial importance across multiple certification systems in foreign jurisdictions and started to gain importance in Turkey. The study also aims todetermine the weights of these criteria.

Land management is defined as the decision-making process of existing land management policies supporting the increasing population with the efficient use of resources, protecting the environment, creating livable settlements by developing social and technical infrastructure areas, protecting drainage basins and wetlands, providing transportation similar to the economic incomes of the immovable property market, and supporting state services supplied with taxes and fees $[4,5,6]$. 
One of the most important issues in green building projects is land selection. Operations such as land use, planning, evaluation, preparation of zoning plans, land and estate arrangements are important stages of the project. In studies conducted in many parts of the world, studies such as the use of materials for green building projects, utilization of renewable energy systems, management of waste materials have been performed, but not much attention has been paid to land management. This study discusses the title 'land management' and proposes a potential land management certification system to be created for Turkey. Sub-criteria for the prosed certification system are also identified, and the weights of these criteria are to be determined after the survey. Additionally, the benefits of green buildings and green building certification systems for both the economy and the people are set out and the necessity of establishing a national certification system is re-emphasised.

\section{Sustainability}

While the population of people living in urban settings constituted $10 \%$ of the total world population just after the Industrial Revolution in the early 19 th century, it is over $50 \%$ today. The increase in migration from villages to cities and the ensuing rapid, inadequate, and substandard structures caused by this migration have unfortunately caused many environmental problems. These problems, such as the decrease in natural energy sources, the degradation of the ecological balance, and particularly global warming (which stands out especially with recent various natural disasters), and environmental pollution have become current issues in many countries around the world and present the biggest problems of a constantly and rapidly changing world. This situation has motivated people to plan for a clean, healthy, livable environment for future generations [7].

Due to the growth in the world population and industrialization along with technological advancement and globalization, the need for natural resources and energy has increased, and that brought along the demand for renewable energy resources. In this context, in order to deliver a more liveable and healthy world to future generations, the world has started to prioritize the concept of sustainability [8].

Sustainability is an environmentalist world view that argues that regional development should be realized by protecting balance of nature, and that environmental values and natural resources should not be used extravagantly but through more rational methods that consider the benefist to present and future generations while also aiming to ensure economic development [9].

In another respect, sustainability is perceived mainly as the ability to sustain the functions, processes, and productivity of ecological systems and ecology in the future $[10,11]$.

Sustainability ensures social and intergenerational equality as well as enhancing the quality of life and economic efficiency. It maintains and increases environmental quality, combines disaster elasticity and impact reduction conceptions, and exhibit a participatory and reconciliatory approach in the decisionmaking process $[12,13]$. 
Taking into account the concept of energy consumption, which has been a necessity since the beginning of humanity, with the concept of sustainability, will provide more sensitivity in the context of protecting energy resources, using them efficiently, and considering the needs of future generations [14].

The concept of sustainability has become an often discussed concept and today is used along with many related jargons such as sustainable cities, sustainable architecture, the sustainability of wetlands, and sustainable agriculture.

\section{Green Buildings}

Green buildings emerged out of a global response that resulted from the increasing carbon footprint of people due to global climate change. According to the United Nations Environment Programme, buildings are estimated to affect $30 \%$ of greenhouse gas emissions [15]. Green buildings, which are high-tech immovables that are sensitive to the effects of buildings on the environment and human health, are those that utilize waste water, renewable energy sources, daylight, have effective heat insulation, and produce the energy needed to sustain themselves. For green buildings to be successful, the location (orientation), design, material selection, construction, operation, maintenance, transportation and reuse of buildings should be considered carefully [16].

In addition to green buildings providing the integration of people with nature, they also are built to protect the health of the people living in them, to increase the productivity of workers, to use natural resources efficiently, and to minimize environmental damage. In order to achieve the above-mentioned objectives, renewable energy sources such as solar and wind energy need to be used so that buildings can generate their own energy. Additionally, buildings should be designed to benefit from daylight as much as possible and they should have an effective heat insulation. An efficient solid waste management system also needs to be created, alongside use of local materials and the need to obtain an environment-friendly appearance [17].

It is estimated that in the total consumption of energy all over the world as well as in Turkey, the energy consumption for heating, cooling, aerating, illumination of buildings and hot water is $30 \%$. In addition to that, if the amount of energy consumed for the construction of industrial productions, such as concrete, glass, wood, electrical materials, plumbing equipment used in buildings and construction machines used for construction is taken into account, the total energy consumption exceeds $40 \%$. Considering such issues, sustainability in buildings ranging from the material that constitutes the building to the process of evaluating the sections that can be reused in the building when the building completes its life can be defined as minimizing the amount and cost of energy inputs (energy, water, building materials, etc.) based on fossil fuels. In this context, green buildings are the buildings where the inputs are used at an efficient and minimum level and the indoor environment quality (comfort) is provided at a high level [3].

While green buildings create healthy and comfortable buildings for people, they have to be shaped according to the needs of countries. Since the growth levels and geographical conditions of the countries are different, they are designed by considering each country's priorities [18]. For example, green buildings 
in China are designed to reduce pollution throughout the entire life cycle as the main importance, while maintaining resources such as energy, soil, water, and materials [19]. Especially in recent years, increasing air pollution and global warming have led to a rapid increase in green building construction. For example, in 2015, worldwide a total of 16 national or regional overtemperature records were broken, including in Venezuela, Germany, Hong Kong, and Indonesia [20, 21]. In the same year, 3,275 people died in France due to heatwaves, while this number was recorded as 2,248 in India [22]. This led to the conclusion that the world serious steps must be taken, and the importance of green building has increased further.

Green buildings provide many environmental, economic, and social benefits. Some of the main benefits of green buildings are as follows [23, 24]:

- Protect the ecosystem,

- Increase efficiency,

- Reduce the emitting of carbon dioxide caused by buildings,

- Minimize the environmental damage that occurs during the construction phase,

- Reduce operating expenses,

- Ensure the use and development of renewable energy,

- Utilize waste produced by excavation,

- Collect and use rain water through green roof application,

- Benefit from natural light,

- Economize energy consumption,

- Reduce heating and cooling costs with insulation systems,

- Increase the value of the building,

- Offer users a healthier and more efficient environment, and

- Add value to urban living spaces.

\section{Green Building Certification Systems}

Certificate systems have been developed to measure the sustainability level of green buildings and to provide the best application experience at the highest certification level. In line with the criteria given, the design, construction, and operation of sustainable buildings are supposed to be certified. The most commonly used criteria sre sustainable development, human and environmental health, water saving, material selection, quality of indoor life, social status, and economic quality for the whole building by determining either a sustainable building approach such as ability to achieve energy efficiency or the performance of the building at key points [25]. Green building certification systems have been designed to provide a framework for building design and building construction where performance targets are met for land use by building employees and other users, energy and water efficiency, indoor quality of life, and other factors. A green building certification system is a relatively more recent and distinct concept than building standards [26]. It includes the following: 
- Creates a verifiable method and framework to help employees make design, construction, restoration, and business management more sustainable,

- Certifies a design or business in line with performance goals,

- Certifies design and operating results and strategies used in constructing a building.

Certification systems are the most valid methods used to identify and classify sustainable buildings according to certain criteria. They determine from which aspect buildings are considered green and turn the concept of green buildings into reality. Certification systems aim to define what constitutes a green building by setting certain evaluation standards in order to develop a design method for the whole building, promote green competition by recognizing environmental leadership in the building sector, and transform the building market by raising awareness of the consumers regarding the benefits of green buildings [3].

Apart from BREEAM in the United Kingdom and LEED in the United States, the most prominent green building certification systems in the world include Canada's SBTOOL which is recognized as an international system; HKBEAM and CEPAS, used in Hong Kong; GREEN STAR used in Australia; and CASBEE, used in Japan. This certification systems are given in Fig. 1.

(Fig. 1)

\section{Material And Method}

In this study, a survey was conducted to highlight the importance of the category of land management, one of the criteria of the green building certification systems, and to identify sub-criteria under this title more objectively. Worldwide valid certification systems and parts of the certification systems regarding land management that are tried to be established in Turkey were examined to determine the survey questions and in line with this, a literature review was performed. The experts in Turkey were interviewed to gather ideas and insights. By listing the answers from these experts using the AHP method, the criteria and sub-criteria of land method were determined and are shown in Table 1. 
Table 1

Land management criteria determined by literature study and experts view

\section{B-Building Features}

B1. Being Functional

B2. Project Design

B3. Establish Health and Comfort

B4. Appropriate to Urban Aesthetics

B5. Being Environment Friendly

B6. Being Energy Efficient

B7. Providing Water-Saving

B8. Having Waste Management

B9. Using Renewable Energy

B10. Having Material Management

B11. Being Economical

B12. Using Recycled Material

B13. Being Innovative

\section{E-Protection of Ecological Values and Properties of the Land}

E1. Protection of Underground and Surface Waters

E2. Protection of Biodiversity

E3. Protection of Wetlands and Coastal Regions

E4. Reuse of the Land

\section{A-Land Properties}

A1. Ambient Air Quality

A2. Solar Energy Potential

A3. Renewable Energy Source Potential

A4. Land Constraints

A5. Ecological Structure of the Region

A6. Climate Conditions of the Region

A7. Wind Energy Potential 


\begin{tabular}{|l|} 
A8. Cultural Heritage of the Region \\
A9. Topography of the Land \\
A10. Geological Structure of the Land \\
A11. Geothermal Energy Potential \\
A12. Zoning Status of the Land \\
\hline A13.Demographic Structure of the Region \\
\hline A14. Market Value \\
\hline K- Proximity to Urban Equipments and Transportation Networks \\
\hline K1. Proximity to Bicycle Roads and Sport Areas \\
\hline K2 Proximity to Metro and Light Rail Systems \\
\hline K3. Proximity to Rest and Recreation Areas \\
\hline K4. Proximity to Public Service Areas \\
\hline K5. Proximity to Commercial Facilities and Living Centers \\
\hline K6. Proximity to Health and Personal Care Facilities \\
\hline K7. Proximity to Culture and Art Centers \\
\hline R- Identification of Risks \\
\hline R1. Natural Disaster Risk \\
\hline R2. Risk of Human Disaster \\
\hline R3. Security \\
\hline R4. Proximity to Garbage Collection Points \\
\hline R5. Proximity to Treatment Plants \\
\hline R6. Proximity to Animal Shelters \\
\hline
\end{tabular}

In the AHP method, there is a hierarchical structure consisting of goals, criteria, qualifications and alternatives and among these, weights are revealed according to the ratio scale from the preferences expressed in the form of binary comparisons by the decision maker. Once these weights are transformed into holistic weights or priorities for options with the help of linear-additive model, the options are ranked according to the priority value results [27].

AHP does not recommend a mandatory method for use, instead it enables decision-makers to use their own capacity, leading them to make them take better decisions [28].

AHP application consists of five steps [28,29]: 
Structuring decision hierarchy,

Collecting data with one-to-one comparisons,

Checking the consistency of objective judgements,

Using the eigenvector method to calculate weights, and

Combining weights to determine the order of decision alternatives

An objective function forms the top layer of the AHP hierarchy. Under this objective there are criteria, subcriteria, and options respectively. The use of the hierarchy is an effective way of dealing with complex systems. While enabling system organization, it also enables in-system information control and communication. It is therefore functionally active [30]. Figure 2 shows a simple AHP model.

Criteria that make up the hierarchy is scored according to a certain scale through binary comparisons. Table 2 shows the rating scale used in AHP.

Table 2

AHP rating scales

\begin{tabular}{|lll|}
\hline $\begin{array}{l}\text { Level of } \\
\text { Importance }\end{array}$ & Definiton & Interpretation \\
\hline 1 & $\begin{array}{l}\text { Equally } \\
\text { preferred }\end{array}$ & Two activities contribute equally to the objective \\
\hline 3 & Moderately & $\begin{array}{l}\text { Experience and judgment slightly favour one activity over another } \\
\text { Experience and judgment strongly or essentially favour one activity } \\
\text { over another }\end{array}$ \\
\hline 7 & Strongly & $\begin{array}{l}\text { An activity is strongly favoured over another and its dominance } \\
\text { demonstrated in practice. }\end{array}$ \\
\hline 9 & Strongly & $\begin{array}{l}\text { The evidence favouring one activity over another is of the highest } \\
\text { degree possible for affirmation }\end{array}$ \\
\hline $2,4,6,8, \ldots$ & $\begin{array}{l}\text { Extremely } \\
\text { values }\end{array}$ & Used to represent a compromise between preferences listed above \\
\hline
\end{tabular}

Survey questions were prepared according to these identified criteria, and they were sent to 3,270 instructors working in all architecture, urban and regional planning, and civil engineering departments in Turkey, and meaningful answers were received from 148 of those people. Since the concept of green building and green building certification system has only recently gainedimportance in Turkey, the number of instructors who can give realistic answers to the questionnaire is low.

In order for land management to gain a social dimension, the requirements of the factors that constitute the demographic structure of society and the standards required for a high quality of life should be determined. Thus, the balance between social norms are focused, thereby ensuring social equality. In this 
context, two different surveys were conducted in order to identify national needs, to understand the level of awareness of green buildings, and to determine the criteria related to land management. The first one was conducted in accordance with the Delphi technique, a systematic information collection method, in order to evaluate specific questions or issues, but the survey could not be concluded because the number of specialists in this field was insufficient, and the groups made up of these specialists did not share information since they were in competition with each other. In the other survey study, participants were asked to give a score from 1 to 5 to the survey questions prepared according to criteria in the literature, and the weights of the criteria were calculated according to the data obtained.

The frequencies and percentages of the answers given to the survey questions were determined according to five different answers including unimportant, less important, moderately important, important, and very important. These were used in determining the weights of sub-criteria of the criteria determined under the category of land management. The averages and standard deviations of the answers were calculated as a next step. According to these calculations, the main criteria and sub-criteria were sorted by their own weights. Within this scope, averages and standard deviations were calculated as follows:

$$
\mathrm{K}_{\mathrm{o}}=\frac{\mathrm{N}}{\mathrm{n}}
$$

$\mathrm{K}_{\mathrm{o}}=$ Criteria mean

$\mathrm{N}=$ The total of scores given by the participants to the relevant criteria

$\mathrm{n}=$ The number of participants

The standard deviation is calculated by taking the square root of the variance.

$$
S=\sqrt{\frac{\sum\left(\mathrm{N}_{\mathrm{i}}-\mathrm{K}_{0}\right)^{2}}{\mathrm{n}-1}}
$$

$S=$ Standard deviation

$\mathrm{N}_{\mathrm{i}}=$ The score given by participant to the i question

$\mathrm{K}_{\mathrm{o}}=$ Criteria mean

$\mathrm{n}=$ Number of participants

The calculated mean, standard deviation, weight, and sorting are shown in Table 3. The main criteria for sorting according to calculated weights was found to be building features, protection of ecological values and properties, land properties, proximity to urban equipment and transportation networks, and 
identification of risks. The weight of the main criterion building features was calculated as 4.4543 , that of protection of ecological values and properties of land as 4.3851, that of land properties as 4.0589 , that of proximity to urban equipment and transportation networks as 3.3861, and that of identification of risks as 3.5045. The sub-criteria were also aligned by their own weights. 
Table 3

Mean, standard deviation, weight and importance sorting of survey data

\begin{tabular}{|c|c|c|c|c|c|c|}
\hline $\begin{array}{l}\text { Main } \\
\text { Criterion }\end{array}$ & Sub Criterion & Mean & $\begin{array}{l}\text { Standard } \\
\text { Deviation }\end{array}$ & $\begin{array}{l}\text { Main } \\
\text { Criterion } \\
\text { Weight }\end{array}$ & $\begin{array}{l}\text { Main } \\
\text { Criterion } \\
\text { Order }\end{array}$ & $\begin{array}{l}\text { Sub } \\
\text { Criterion } \\
\text { Order }\end{array}$ \\
\hline \multirow{14}{*}{$\begin{array}{l}\text { Building } \\
\text { Features }\end{array}$} & Being Economical & 4,1689 & 0,81973 & & & 11 \\
\hline & Being Functional & 4,8311 & 0,41055 & & & 1 \\
\hline & $\begin{array}{l}\text { Appropriate to Urban } \\
\text { Esthetics }\end{array}$ & 4,6486 & 0,59321 & & & 4 \\
\hline & $\begin{array}{l}\text { Being Environment } \\
\text { Friendly }\end{array}$ & 4,6284 & 0,60923 & & & 5 \\
\hline & Using Recycled Material & 3,9932 & 0,95829 & & & 12 \\
\hline & Being Innovative & 3,8446 & 0,98777 & & & 13 \\
\hline & Being Energy Efficient & 4,6149 & 0,6072 & & & 6 \\
\hline & Providing Water-Saving & 4,5541 & 0,6312 & 4,4563 & 1 & 7 \\
\hline & $\begin{array}{l}\text { Having Waste } \\
\text { Management }\end{array}$ & 4,4459 & 0,78492 & & & 8 \\
\hline & Project Design & 4,7838 & 0,50225 & & & 2 \\
\hline & Using Renewable Energy & 4,4257 & 0,72928 & & & 9 \\
\hline & $\begin{array}{l}\text { Having Material } \\
\text { Management }\end{array}$ & 4,2095 & 0,8186 & & & 10 \\
\hline & $\begin{array}{l}\text { Establish Health and } \\
\text { Comfort }\end{array}$ & 4,7568 & 0,51668 & & & 3 \\
\hline & Reuse of Land & 4,2973 & 0,88417 & & & 4 \\
\hline \multirow{7}{*}{$\begin{array}{l}\text { Protection } \\
\text { of } \\
\text { Ecological } \\
\text { Values and } \\
\text { Properties } \\
\text { of Land }\end{array}$} & $\begin{array}{l}\text { Protection of Wetlands } \\
\text { and Coastal Regions }\end{array}$ & 4,3784 & 0,88376 & 4,3851 & 2 & 3 \\
\hline & Protection of Biodiversity & 3,3851 & 0,87694 & & & 2 \\
\hline & $\begin{array}{l}\text { Protection of } \\
\text { Underground and Surface } \\
\text { Waters }\end{array}$ & 4,4797 & 0,82865 & & & 1 \\
\hline & Land Constraints & 4,3581 & 0,83308 & & & 5 \\
\hline & $\begin{array}{l}\text { Renewable Energy } \\
\text { Source Potential }\end{array}$ & 4,3581 & 0,76497 & & & 4 \\
\hline & Ambient Air Quality & 4,6622 & 0,62329 & & & 1 \\
\hline & Market Value & 3,2838 & 1,18402 & & & 14 \\
\hline Land & Zoning Status of the & 3,7297 & 1,12845 & & & 12 \\
\hline
\end{tabular}


Features Land

\begin{tabular}{|c|c|c|c|c|c|}
\hline Topography of the Land & 3,9392 & 1,17355 & & & 9 \\
\hline $\begin{array}{l}\text { Geological Structure of } \\
\text { the Land }\end{array}$ & 3,9257 & 1,05683 & & & 10 \\
\hline $\begin{array}{l}\text { Climate Conditions of the } \\
\text { Region }\end{array}$ & 4,3041 & 0,98048 & 4,0589 & 3 & 6 \\
\hline $\begin{array}{l}\text { Cultural Heritage of the } \\
\text { Region }\end{array}$ & 4,0338 & 1,13937 & & & 8 \\
\hline $\begin{array}{l}\text { Demographic Structure } \\
\text { of the Region }\end{array}$ & 3,4595 & 1,13316 & & & 13 \\
\hline $\begin{array}{l}\text { Ecological Structure of } \\
\text { the Region }\end{array}$ & 4,3243 & 0,92004 & & & 3 \\
\hline Solar Energy Potential & 4,4595 & 0,86801 & & & 2 \\
\hline Wind Energy Potential & 4,1622 & 1,01723 & & & 7 \\
\hline $\begin{array}{l}\text { Geothermal Energy } \\
\text { Potent }\end{array}$ & 3,8243 & 1,10482 & & & 11 \\
\hline
\end{tabular}

\begin{tabular}{|c|c|c|c|c|c|c|}
\hline \multirow{5}{*}{$\begin{array}{l}\text { Proximity to } \\
\text { Urban Equipments } \\
\text { Transportation } \\
\text { Networks }\end{array}$} & Proximity to Public Service Areas & 3,3243 & \multicolumn{2}{|l|}{1,26822} & & 4 \\
\hline & $\begin{array}{l}\text { Proximity to Metro and Light Rail } \\
\text { Systems }\end{array}$ & 3,9122 & 1,15428 & & & 2 \\
\hline & $\begin{array}{l}\text { Proximity to Rest and Recreation } \\
\text { Areas }\end{array}$ & 3,5135 & 1,18084 & 3,6108 & 4 & 3 \\
\hline & $\begin{array}{l}\text { Proximity to Bicycle Roads and Sport } \\
\text { Areas }\end{array}$ & 3,9865 & 1,03655 & & & 1 \\
\hline & $\begin{array}{l}\text { Proximity to Commercial Facilities } \\
\text { and Living Centers }\end{array}$ & 3,3176 & 1,07562 & & & 5 \\
\hline & Proximity to Culture and Art Centers & 4,4932 & 0,90724 & & & 1 \\
\hline & $\begin{array}{l}\text { Proximity to Health and Personal } \\
\text { Care Facilities }\end{array}$ & 4,3378 & 1,05337 & & & 2 \\
\hline & Natural Disaster Risk & 3,8108 & 1,32661 & & & 3 \\
\hline Identification of & Risk of Human Disaster & 2,7838 & 1,18115 & 3,3345 & 5 & 7 \\
\hline \multirow[t]{4}{*}{ Risks } & Security & 2,8649 & 1,14671 & & & 5 \\
\hline & $\begin{array}{l}\text { Proximity to Garbage Collection } \\
\text { Points }\end{array}$ & 3,2568 & 1,28371 & & & 4 \\
\hline & Proximity to Animal Shelters & 2,277 & 1,12981 & & & 8 \\
\hline & Proximity to Treatment Plants & 2,8514 & 1,37205 & & & 6 \\
\hline
\end{tabular}




\section{Findings And Discussion}

The rapid increase in the number of consumers in our societies has caused a significant waste management problem as well as other problems such as global warming and climate change, degradation of natural vegetation and soil resources, reduction of water resources and drinking water, destruction of biodiversity,damage to the ozone layer, and environmental pollution. While waste did not cause much problem in society before, it has grown over time and reached a level that will threaten the entire world ecosystem. Environmentalists have rallied behind the concept of sustainability and this concept has been applied in many important areas, including the construction sector, with a sustainable development perspective [32].

The fact that energy consumption in buildings constitute $40 \%$ of overall energy consumption has led the construction sector to make more sustainable and environmentally friendly buildings and has led to the concept of green building. As green building projects got off the ground, green building certification systems have been created to evaluate the environmental impact of these buildings, and to measure and document energy efficiency.

Green building certification systems examine buildings based on a multitude of criteria and scores and certifies them. One of the most important topics of green building certification systems is land management. To understand this concept in the best way possible and to elaborate on this concept within the scope of a green building project are very important for the success of green building projects. Social, economic and ecological components that form the basis of sustainability for effective land management in a green building project need to be understood and utilised in the best way possible.

In order for the land management concept to gain an economic dimension, it should be aimed to create a system which is suitable for the socio-economic structure, decreasing the costs while increasing the efficiency, enabling the use of recycled materials and maintaining the balance with the production sector as well as the environmental values. To give an economic dimension to the criteria created for this purpose, criteria such as cost effectiveness analysis, use of recycled materials, energy efficiency, renewable energy use, material management were added to the system.

Land management, which aims to preserve the biodiversity, wetlands and coastal areas based on the reuse of land for the purpose of preserving the ecological value and characteristics of the region, ensures that natural balance is maintained by reducing environmental degradation. Criteria such as ambient air quality, waste management, environmental friendliness, protection of underground and surface water were added in order to provide ecological dimension to the criteria set for this purpose.

The percentages of the 5 different responses (not important, less important, moderately important, important, very important) given to the questionnaire were calculated to be used to determine the weight of the criteria and sub-criteria of land management. The percentage of each sub-criterion within all criteria is calculated as follows: 
$K_{i}=\left(\frac{n_{i}}{\sum n_{i}}\right) * 100$

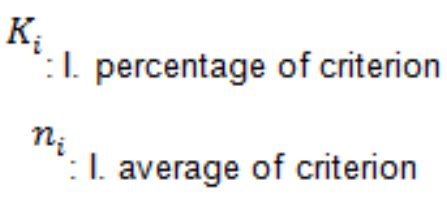

Green buildings and green building certification systems have been gaining importance in the world as well as in Turkey, and meetings and seminars were delivered to create awareness and put forward new ideas since 2012. The Green Buildings Summit, which has been taking place since 2012 and is organized every year, is an indicator of the awareness of the green building concept in our country. At the first summit, urban transformation and sustainability issues were the most prominent. It was also mentioned that green buildings are no longer luxury and have become day-to-day necessity. At the end of the summit, the final declaration stated that green building projects should be designed for urban transformation applications and especially for energy efficiency in the transformation of shanty houses, and that among those shanty houses, the ones that are in good condition can be reused after restoration. It was emphasized that the costs of green buildings are now approaching and levelling traditional building costs, that the savings provided by green buildings in terms of the country's economy are significant, and that the green housing certification should be supported by law.

The 2nd International Green Buildings Summit, which was held in 2013, addressed the theme of green transformation and linked the solution of environmental, economic and sociological problems to these transformations. At this summit, it was highlighted that public participation is very important in this transformation, and that in order to increase savings associated with green buildings, energy efficiency should be focused on existing buildings.

The following points were emphasized in the decisions taken at the 3rd International Green Buildings Summit in 2014 , concepts such as sustainability and liveability will gain a meaning only when they are realized; these should be the basic concepts and principles in the process of urban transformation; and in order to realize the concept of sustainability and green transformation, human behavior should be changed first.

In the 4th Green Building Summit held in 2016, the main theme was sustainable efficiency and building management. At the summit, it was mentioned that the energy efficiency is inevitable, that there are savings and advantages associated with the process; and that it is necessary to implement energy efficiency projects in the public sector. It was revealed that building management impacts the cost significantly, and that all the owners of the building should adopt the building management throughout the life span of the building by explaining how energy saving can be achieved in buildings, and that sustainability should be transferred from generation to generation.

The criteria of land management were determined in line with the decisions taken as a result of these summits, expert opinions, local conditions and needs of our country. In order to determine criteria and 
sub-criteria applicable toland management, the land-related parts of the BREEAM, LEED, SBTOOL, and ÇEDBIK systems were examined. Based on these examinations and local needs, sub-criteria of the land management category were determined to be building features, protection of ecological values and properties of the land, land features, proximity to urban equipment and transportation networks, and identification of risk. The sub-criteria of these criteria were determined and survey questions were prepared for each criterion, These survey questions were then sent to the instructors involved in the discipline of green building certificate systems, and responses were entered into the SPSS program. Firstly, a reliability analysis was performed with SPSS. The reliability analysis made was Cronbach Alpha. As a result of this analysis, the Cronbach Alpha value was found to be 0.921 . The values above 0.9 are considered excellent and this resulted in a perfectly reliable survey. After this analysis, the weights that would be assigned to the criteria were determined according to sorting, scoring, and paired comparison methods. The most important sub-criterion of the building features criterion was found to be functional. 
Table 4

Sorting, scoring and paired comparison methods

\begin{tabular}{|c|c|c|c|c|c|c|}
\hline $\begin{array}{l}\text { Main } \\
\text { Criterion }\end{array}$ & Sub Criterion & $\begin{array}{l}\text { Main } \\
\text { Criterion } \\
\text { Order }\end{array}$ & $\begin{array}{l}\text { Sub } \\
\text { Criterion } \\
\text { Order }\end{array}$ & $\begin{array}{l}\text { Sorting } \\
\text { Method }\end{array}$ & $\begin{array}{l}\text { Scoring } \\
\text { Method }\end{array}$ & $\begin{array}{l}\text { Paired } \\
\text { Comparison } \\
\text { Method }\end{array}$ \\
\hline \multirow{14}{*}{$\begin{array}{l}\text { Building } \\
\text { Features }\end{array}$} & Being Economical & \multirow[t]{13}{*}{1} & 11 & \multirow[t]{13}{*}{0,3333333} & \multirow[t]{13}{*}{0,3846154} & \multirow[t]{13}{*}{0,3599995} \\
\hline & Being Functional & & 1 & & & \\
\hline & $\begin{array}{l}\text { Appropriate to } \\
\text { Urban Esthetics }\end{array}$ & & 4 & & & \\
\hline & $\begin{array}{l}\text { Being Environment } \\
\text { Friendly }\end{array}$ & & 5 & & & \\
\hline & $\begin{array}{l}\text { Using Recycled } \\
\text { Material }\end{array}$ & & 12 & & & \\
\hline & Being Innovative & & 13 & & & \\
\hline & $\begin{array}{l}\text { Being Energy } \\
\text { Efficient }\end{array}$ & & 6 & & & \\
\hline & $\begin{array}{l}\text { Providing Water- } \\
\text { Saving }\end{array}$ & & 7 & & & \\
\hline & $\begin{array}{l}\text { Having Waste } \\
\text { Management }\end{array}$ & & 8 & & & \\
\hline & Project Design & & 2 & & & \\
\hline & $\begin{array}{l}\text { Using Renewable } \\
\text { Energy }\end{array}$ & & 9 & & & \\
\hline & $\begin{array}{l}\text { Having Material } \\
\text { Management }\end{array}$ & & 10 & & & \\
\hline & $\begin{array}{l}\text { Establish Health } \\
\text { and Comfort }\end{array}$ & & 3 & & & \\
\hline & Reuse of Land & \multirow[t]{4}{*}{2} & 4 & \multirow[t]{4}{*}{0,2666667} & \multirow[t]{4}{*}{0,2692308} & \multirow[t]{4}{*}{0,2800010} \\
\hline $\begin{array}{l}\text { Protection } \\
\text { of } \\
\text { Ecological }\end{array}$ & $\begin{array}{l}\text { Protection of } \\
\text { Wetlands and } \\
\text { Coastal Regions }\end{array}$ & & 3 & & & \\
\hline \multirow{4}{*}{$\begin{array}{l}\text { Values } \\
\text { and } \\
\text { Properties } \\
\text { of Land }\end{array}$} & $\begin{array}{l}\text { Protection of } \\
\text { Biodiversity }\end{array}$ & & 2 & & & \\
\hline & $\begin{array}{l}\text { Protection of } \\
\text { Underground and } \\
\text { Surface Waters }\end{array}$ & & 1 & & & \\
\hline & Land Constraints & \multirow[t]{2}{*}{3} & 5 & \multirow[t]{2}{*}{0,2} & \multirow[t]{2}{*}{0,1923077} & \multirow[t]{2}{*}{0,2000049} \\
\hline & $\begin{array}{l}\text { Renewable Energy } \\
\text { Source Potential }\end{array}$ & & 4 & & & \\
\hline
\end{tabular}




\begin{tabular}{|c|c|c|}
\hline & Ambient Air Quality & 1 \\
\hline & Market Value & 14 \\
\hline \multirow[t]{10}{*}{$\begin{array}{l}\text { Land } \\
\text { Features }\end{array}$} & $\begin{array}{l}\text { Zoning Status of } \\
\text { the Land }\end{array}$ & 12 \\
\hline & $\begin{array}{l}\text { Topography of the } \\
\text { Land }\end{array}$ & 9 \\
\hline & $\begin{array}{l}\text { Geological } \\
\text { Structure of the } \\
\text { Land }\end{array}$ & 10 \\
\hline & $\begin{array}{l}\text { Climate Conditions } \\
\text { of the Region }\end{array}$ & 6 \\
\hline & $\begin{array}{l}\text { Cultural Heritage } \\
\text { of the Region }\end{array}$ & 8 \\
\hline & $\begin{array}{l}\text { Demographic } \\
\text { Structure of the } \\
\text { Region }\end{array}$ & 13 \\
\hline & $\begin{array}{l}\text { Ecological } \\
\text { Structure of the } \\
\text { Region }\end{array}$ & 3 \\
\hline & $\begin{array}{l}\text { Solar Energy } \\
\text { Potential }\end{array}$ & 2 \\
\hline & $\begin{array}{l}\text { Wind Energy } \\
\text { Potential }\end{array}$ & 7 \\
\hline & $\begin{array}{l}\text { Geothermal Energy } \\
\text { Potent }\end{array}$ & 11 \\
\hline
\end{tabular}




\begin{tabular}{|c|c|c|c|c|c|c|}
\hline \multirow{5}{*}{$\begin{array}{l}\text { Proximity } \\
\text { to } \\
\text { Urban } \\
\text { Equipments } \\
\text { Transpor- } \\
\text { tation } \\
\text { Networks }\end{array}$} & Proximity to Public Service Areas & \multirow[t]{5}{*}{4} & 4 & \multirow[t]{5}{*}{0,1333333} & \multirow[t]{5}{*}{0,1153846} & \multirow[t]{5}{*}{0,1199992} \\
\hline & $\begin{array}{l}\text { Proximity to Metro and Light Rail } \\
\text { Systems }\end{array}$ & & 2 & & & \\
\hline & $\begin{array}{l}\text { Proximity to Rest and Recreation } \\
\text { Areas }\end{array}$ & & 3 & & & \\
\hline & $\begin{array}{l}\text { Proximity to Bicycle Roads and } \\
\text { Sport Areas }\end{array}$ & & 1 & & & \\
\hline & $\begin{array}{l}\text { Proximity to Commercial } \\
\text { Facilities and Living Centers }\end{array}$ & & 5 & & & \\
\hline & $\begin{array}{l}\text { Proximity to Culture and Art } \\
\text { Centers }\end{array}$ & \multirow[t]{8}{*}{5} & 1 & \multirow[t]{8}{*}{0,0666667} & \multirow[t]{8}{*}{0,0384615} & \multirow[t]{8}{*}{0,0400008} \\
\hline & $\begin{array}{l}\text { Proximity to Health and Personal } \\
\text { Care Facilities }\end{array}$ & & 2 & & & \\
\hline & Natural Disaster Risk & & 3 & & & \\
\hline $\begin{array}{l}\text { Identification } \\
\text { of }\end{array}$ & Risk of Human Disaster & & 7 & & & \\
\hline \multirow[t]{4}{*}{ Risks } & Security & & 5 & & & \\
\hline & $\begin{array}{l}\text { Proximity to Garbage Collection } \\
\text { Points }\end{array}$ & & 4 & & & \\
\hline & Proximity to Animal Shelters & & 8 & & & \\
\hline & Proximity to Treatment Plants & & 6 & & & \\
\hline
\end{tabular}

The concept of green building can be successful if it is implemented in accordance with people's needs and local conditions. A survey was conducted in line with the opinions of the experts for this reason. The decrease in the amount of water resources is a trend that is witnessed not in our country but worldwide. So the most important criteria of the Criterion for the Protection of The Ecological Value and Properties of the Land is determined as the Protection of Underground and Surface Water. As Turkey is located on the North Anatolian Fault Line, there is high earthquake risk in the region. Therefore, the most important criterion of risk criteria is natural disaster risk.

\section{Development Of Land Assessment Pro. Ver. 1.0 Interface}


The land-related parts of the BREEAM, LEED, and SBTool, which are widely used for national needs and all over the world, and of the ÇEDBIK Green Housing certification systems, for which efforts are being made establish in Turkey, were discussed in the study, and the National Green Building Land Criteria (NGBLC) 2017 Ver. 1.0 were created. The results of the survey were evaluated and the weights of NGBLC 2017 Ver. 1.0 were determined for each criterion. Through literature studies scoring methods that are more commonly used were determined, and this method was used to calculate the weights of the criteria. In order for the user to be able to use these criteria efficiently, easily, and rapidly in a computer environment, the Land Evaluation Pro. Give. 1.0 was written to determine the total score that the building will achieve under the land management category, according to the scores of land criteria. This program was created in the $\mathrm{C}$ \# language in the NetFrame Work environment included in the Microsoft Visual Studio 2010 program.

In addition to calculating category scores by loading the NGBLC 2017 Ver. 1.0 criteria, total category scores can also be calculated by loading the criteria into the land categories of other certification systems. The main screen shot of the Land Evaluation Pro. Ver. 1.0 is given in Figure 3.

The desired certification system criteria can be loaded from the download button on the main screen. The loaded state of NGBLC 2017 Ver. 1.0 is shown in Figure 4.

First of all, the total score yielded by the certification system selected by users is entered into the relevant section on the screen. Then, users assign scores from 1 to 5 based on the explanations included in the F1 help menu. A sample display of the F1 help menu is shown in Figure 5.

After all of the values were entered by the user, the value of the land in the certification system was calculated by pressing the calculate button. The calculated sample land value is shown in Figure 6 .

A transfer button was created in Excel in order to archive retroactive evaluation results and to make report in Excel in desired standards. The values that were transferred to Excel are shown in Figure 7.

\section{Conclusion And Suggestions}

The need for a local certification system has increased in order to determine the attributes of green buildings, which have begun to gain importance and are constantly increasing in numbers in Turkey. As a result, different working groups have prepared different certificate systems.

Land management, which is one of the categories that need to be included in this system in the event that a national certification system can be created in Turkey, was discussed, and the criteria and their weights under this category were determined in the study. After a literature search was performed, the criteria were determined to be building features, protection of ecological values and properties of the land, land features, proximity to urban equipment and transportation networks, and identification of risks. The sub-criteria of these criteria were determined by the survey study, and the weights of these sub-criteria were determined by sorting, scoring, and paired comparison methods. 
In our country, buildings are being constructed according to the Energy Efficiency Law. The main objective for the buildings to be constructed according to this law is to reduce the consumption of energy used. It is known that the energy consumption of buildings in our country is currently approximately $35 \%$, and the greenhouse gases emitted from these buildings is up to $30 \%$. The aim is to increase the use of renewable energy resources and thus to reduce damage to the environment with the energy identity document given to the buildings. However, the energy identity document does not fully meet the needs. The creation of a more comprehensive certification system has become a necessity for both the national economy and green cities. Approaches such as tax exemption, mortar exemption, and tax reduction can be applied to encourage people to choose to build new buildings as green ones. With this application, the aim can be, not only for people to live in more comfortable and healthy buildings but also in a greener and more liveable world to be delivered to future generations. All segments of the society should be informed, and their awareness be raised.

The concept of a building management system that provides for computers to be used more intensively than people in order for systems in buildings to be used reliably and healthily has recently entered our lives. This system provides central control and information for operating systems. Systems operate according to a certain time program and through this economize energy consumption. These systems reduce energy costs and errors and increase productivity by providing a periodic maintenance process. So, in order to benefit from these systems it is very important for green buildings to be erected. The integration of building management systems into green buildings will bring many benefits to green building projects.

Our country consists of seven different geographical regions. Each region has its own climate conditions and living standards. People living in these areas have different needs in terms of materials and techniques and natural regional differences. For example, since the amount of precipitation is high in the Black Sea region, it may be necessary to take advantage of rain water in the project. Considering that solar energy potential in the Mediterranean region is higher than other regions, the solar energy aspect of the buildings in this region would be different. Accordingly, the inclusion of additional features in the certificate system for different regionas is bound to provide more realistic results. These can only be achieved by fully understanding the concept of sustainability, creating sustainability policies, andultimately, making them real.

In this study, the need for changing the green building certification system for regional differences was considered. The study can provide a foundation for conducting individual projects. For example, in urban transformation projects, a green building project can be implemented considering the geographical characteristics of the region.

\section{Declarations}

\section{Authors' contributions}


All authors edited and approved the final manuscript.

\section{Funding}

Not applicable.

\section{Availability of data and materials}

Not applicable.

\section{Ethics approval and consent to participate}

Not applicable.

\section{Consent for publication}

Not applicable.

\section{Competing interests}

The authors declare that they have no competing interests.

\section{Author details}

${ }^{1}$ General Directorate of Land Registry and Cadastre- Section 11, Kayseri, Turkey. ${ }^{2}$ Department of Geomatics Engineering, Ondokuz Mayis University, Samsun, Turkey.

\section{References}

1. Bengü D (2012) Assessment of LEED green building certification system during the construction process, models from Turkey. Yıldız Technical University, İstanbul, 253

2. Çelik E (2009) Assessment on green building rating systems and their adaptations to Turkey. Master Thesis, Istanbul Technical University, Istanbul, 117

3. Şimşek EP (2012) The criteria for being green building in context of sustainability -Kağıthane Ofispark Project as an example-. Master Thesis, Istanbul Technical University, Istanbul, 139

4. Dale PF, McLaughlin JD (1988) Land Information Management. Oxford University Press, NewYork, p 169

5. FIG (1995) The FIG Statement on the Cadastre. FIG Publication, 11 
6. Ülger NE (2010) Türkiye'de Arsa Düzenlemeleri ve Kentsel Dönüşüm. Nobel Yayın Dağıtım, Ankara, 372

7. İnanç $T$ (2010) Evaluation of traditional rural architecture identity in the context of ecology and sustainability case of Rize Çağlayan Village houses. Master Thesis, Mimar Sinan Fine Arts University, İstanbul, 150

8. Saka i (2011) Sustainability evaluation of an office building in Istanbul in the scope of LEED certification system. Master Thesis, Istanbul Technical University, Istanbul, 162

9. Keleş R (1998) Kentbilim Terimleri Sözlüğü (2. baskı), İmge Kitabevi Yayınları, Ankara, 224

10. Chapin F, Torn M, Tateno M (1996) Principles of ecosystem sustainability. Am Nat 6(148):10161037

11. Pamuk R, Kuruoğlu M (2016) Sustainability in costruction sector and universal application of building costruction examples. Beykent University Journal of Science Engineering 9(1):161-177

12. Akgül U (2010) Sürdürülebilir kalkınma: Uygulamalı antropolojinin eylem alanı. Antropoloji Dergisi, (24):133-164

13. Mileti DS (1999) Disasters by Design: A Reassessment of Natural Hazards in the United States. Joseph Henry Press, Washington D.C., 371

14. Yılmaz E (2019) Evaluation of ecological sustainability angle green building certification system in Turkey. Master Thesis, İstanbul Aydin University, İstanbul, 187

15. United Nations Environment Programme Sustainable Buildings \& (2009) Climate Initiative, Buildings and Climate Change: Summary for Decision-Makers. France, Paris

16. Yudelson J (2008) The Green Building Revolution. Island Press, Washington, p 272

17. Real Estate. https://www.zillow.com/rental-manager/resources/? source=topnav\&itc=postbutton_topnav (accessed: 15.12.2015)

18. Işıldar GY, Gökbayrak A (2018) Evalution of green building criteria according to development level of countries. Ömer Halisdemir Üniversitesi Mühendislik Bilimleri Dergisi 7(1):46-57

19. Ding Z, Fan Z, Tam VWY, Bian Y, Li IMCS, Illankoon S, Moon S (2018) Green building evaluation system implementation. Build Environ 133:32-40

20. Sixteen National/Territorial All-Time Extreme Heat Records Set in 2015, Weather Underground (accessed: 16.04.2020)

Masters J (2016) Sixteen National/Territorial All-Time Extreme Heat Records Set in 2015, Weather Underground. https://www.wunderground.com/blog/JeffMasters/sixteen-nationalterritorial-alltimeextreme-heat-records-set-in-2015.html (accessed: 16.04.2020)

21. Houghton A, Castillo-Salgado C (2020) Analysis of correlations between neighborhood-level vulnerability to climate change and protective green building design strategies: A spatial and ecological analysis. Building and Environment, 168 (2020)

22. U.N. Office for Disaster Risk Reduction (2016) U.S. AID, Universite Catholique de Louvain Centre for Research on the Epidemiology of Disasters, 2015. Disasters in Numbers. https://www.cred.be/2015- 
disasters-numbers (accessed: 25.04.2020)

23. Kubba S (2010) Green Construction Project Management and Cost Oversight. ButterworthHeinemann, USA, p 560

24. Designing Buildings Wiki.See https://www.designingbuildings.co.uk/wiki/Bottomup_approach_to_address_the_challenges_of_low-carbon_eco-cites (accessed 06.12.2015)

25. Bauer M, Mösle P, Schwarz M (2010) Green Building: Guidebook for Sustainable Architecture, 210. Springer, Springer-Verlag Berlin Heidelberg

26. National Research Council of the National Academies (2013) Energy-Efficiency Standards and Green Building Certification Systems. The National Academies Press, Washington, D.C., p 218

27. Çınar Y (2004) Multi attribute decision making and an implementation on evaluation of financial performances of banks. Ankara University, Ankara, 240

28. Çelikyay S (2002) Selection of the multi-role fighter aircraft with using multi-attribute decision making methods. Master Thesis, Istanbul Technical University, Istanbul, 148

29. Canada JR, Sullivan WG, White JA (1996) Capital Investment Analysis for Engineering and Management (3th edition). Pearson, London, 624

30. Topcu Y (2000) Integrated decision aid model for multiattribute problem solving. PhD. Thesis, Istanbul Technical University, Istanbul, 261

31. Saaty TL (1980) The Analytic Hierarchy Process. McGraw-Hill, New York, p 287

32. Sırkıntı H (2012) As part of sustainability implementation of green construction and proposition to LEED certification system, Master Thesis, Istanbul Technical University, Istanbul, 133

\section{Figures}




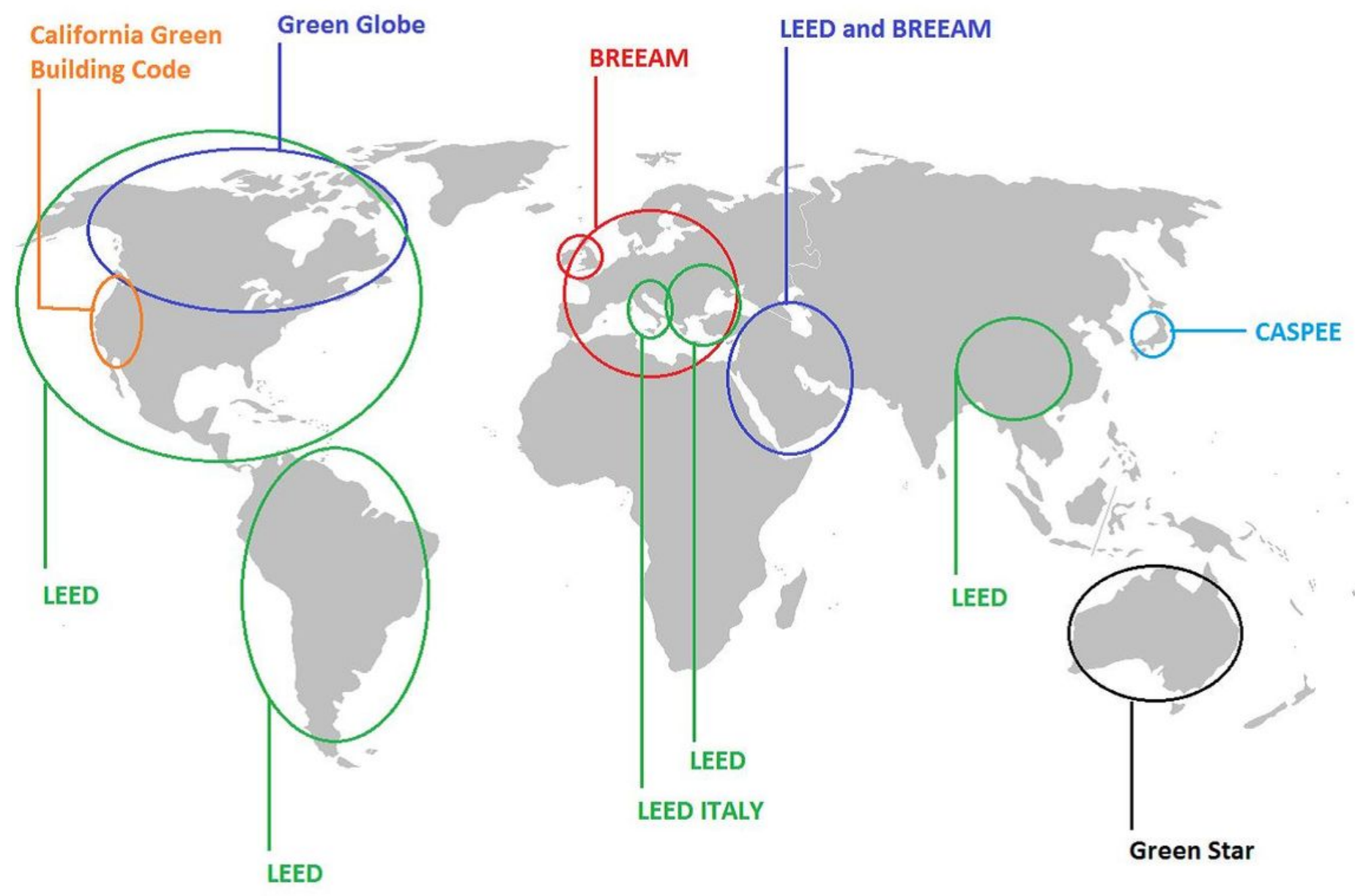

Figure 1

Commonly used certification systems in the world [1] Note: The designations employed and the presentation of the material on this map do not imply the expression of any opinion whatsoever on the part of Research Square concerning the legal status of any country, territory, city or area or of its authorities, or concerning the delimitation of its frontiers or boundaries. This map has been provided by the authors. 


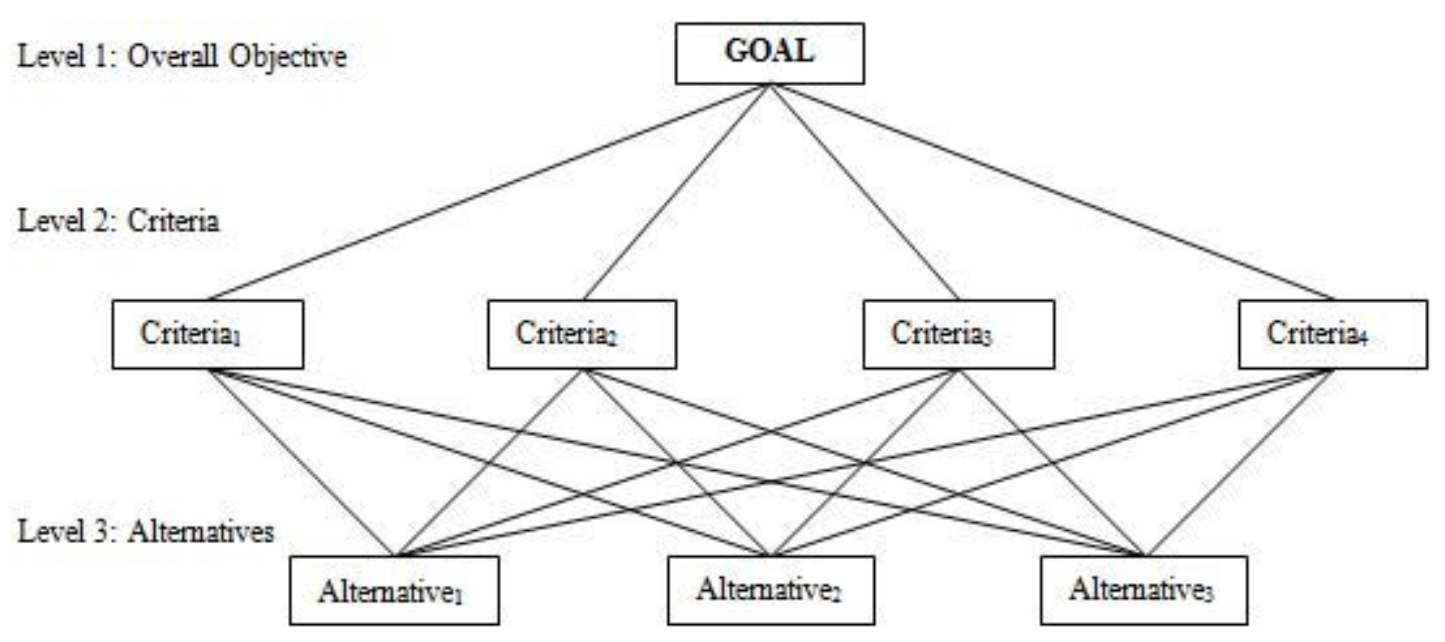

\section{Figure 2}

A simple AHP model

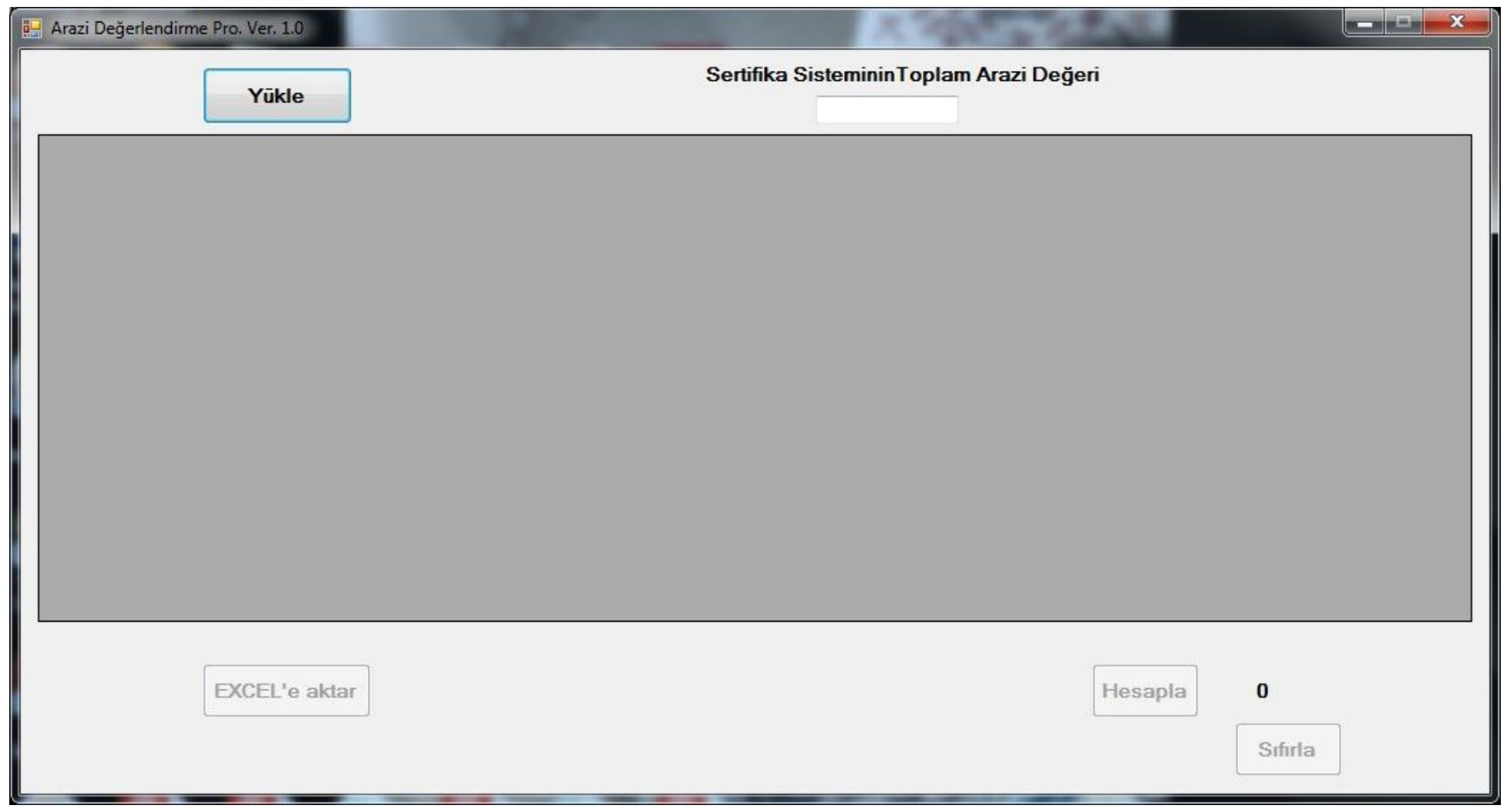

Figure 3

The main screen shot of the program 


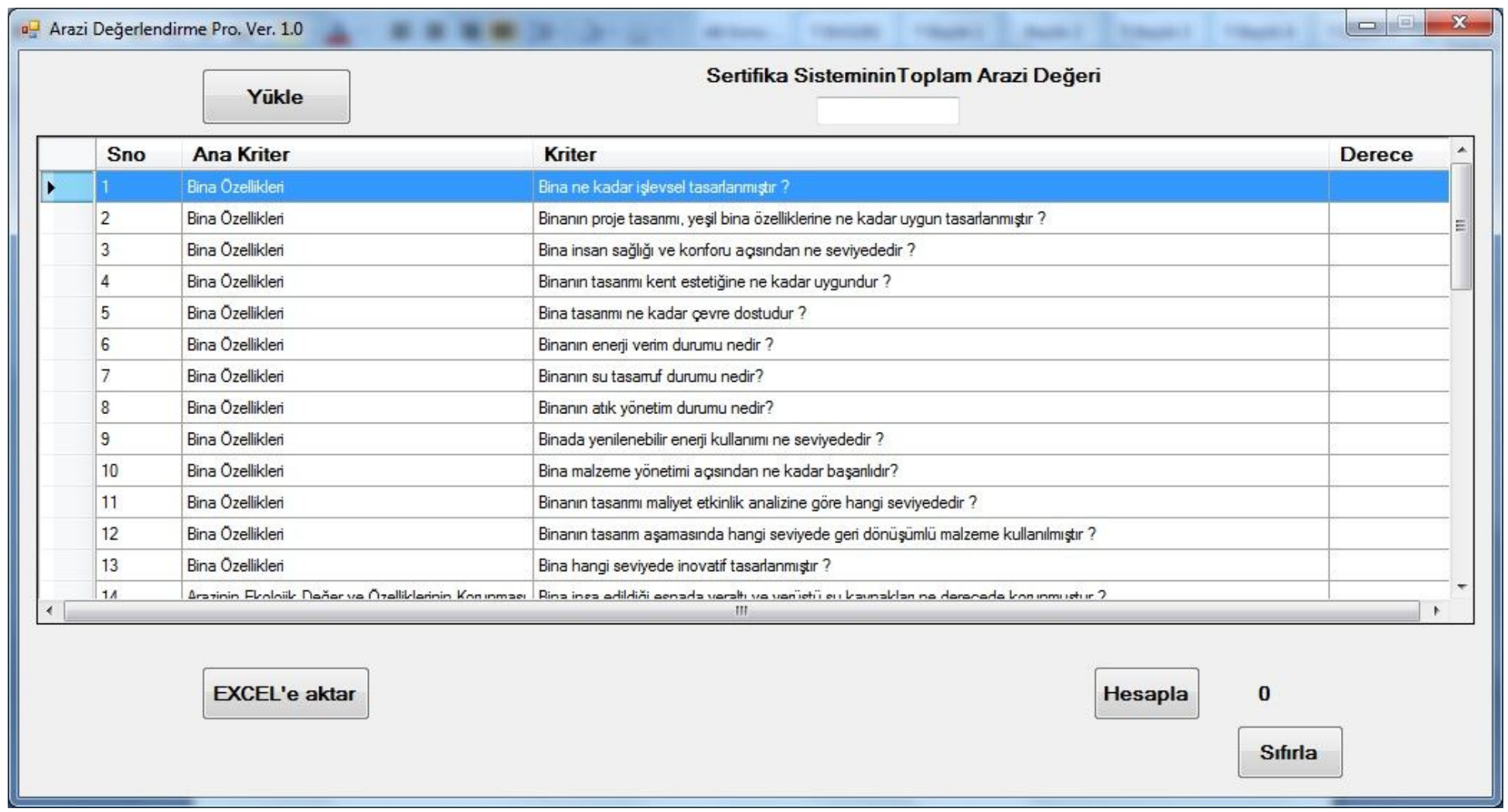

\section{Figure 4}

The loaded state of NGBLC 2017 Ver. 1.0 . F1 help menu

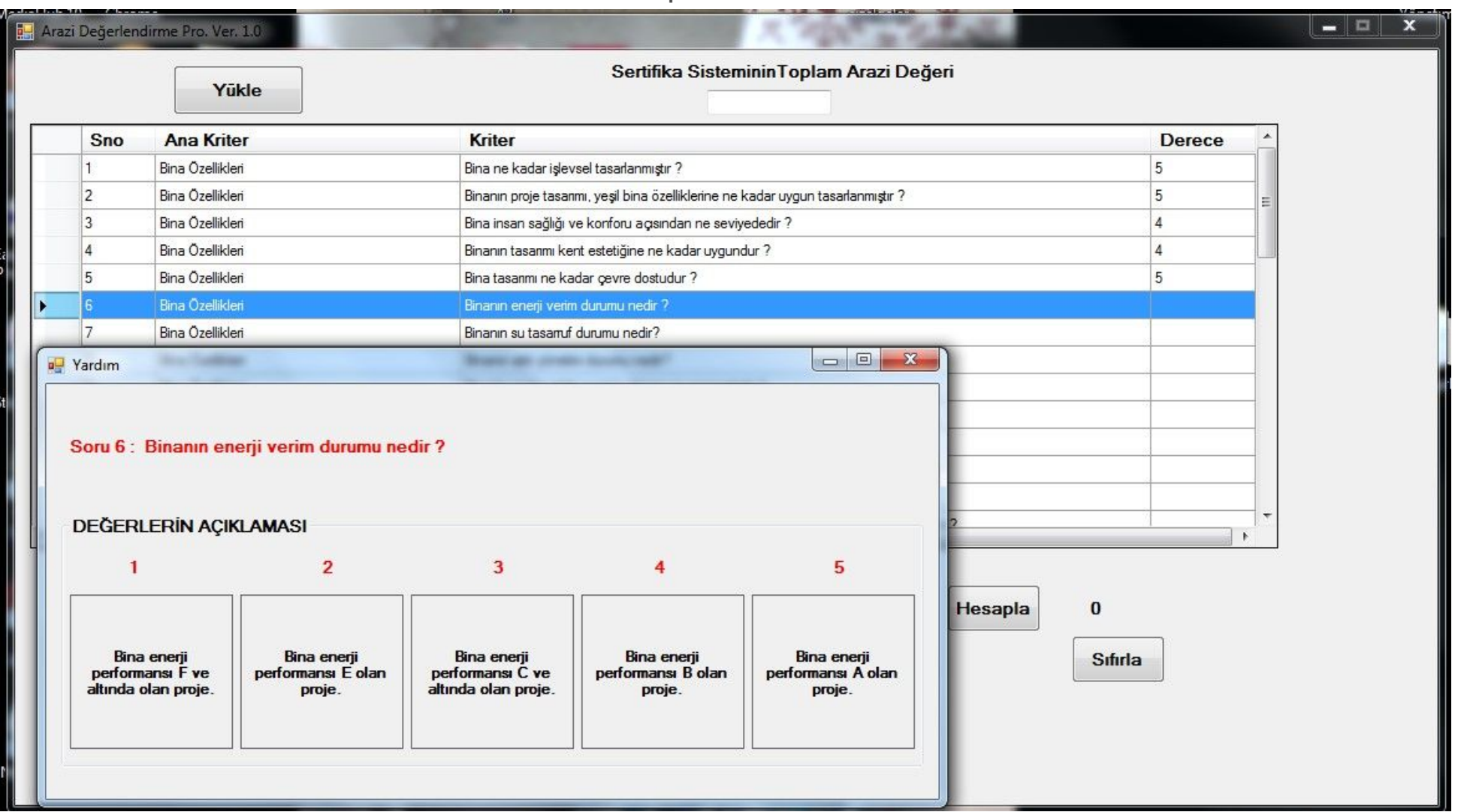

\section{Figure 5}




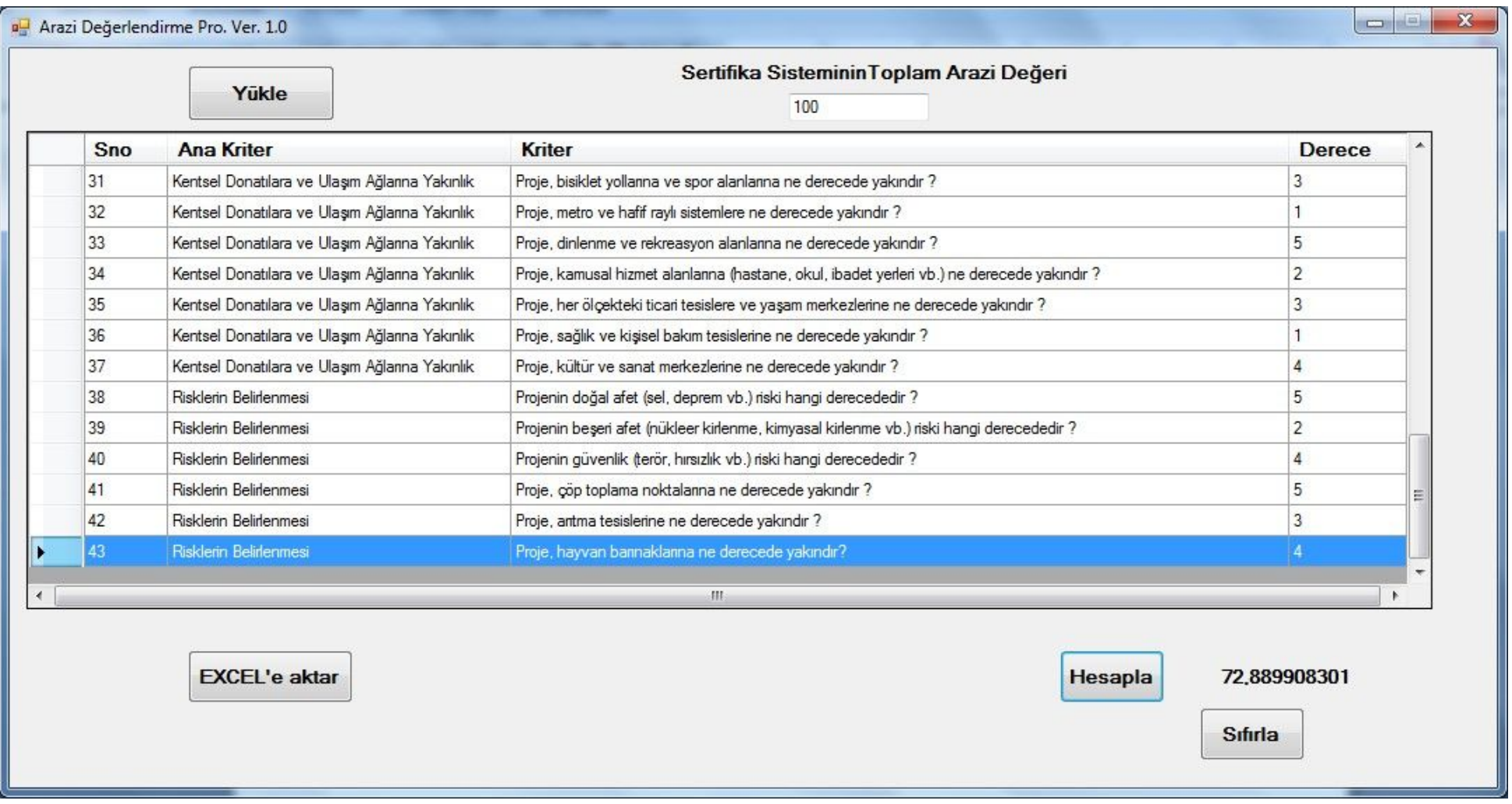

\section{Figure 6}

\section{A calculated sample land value}

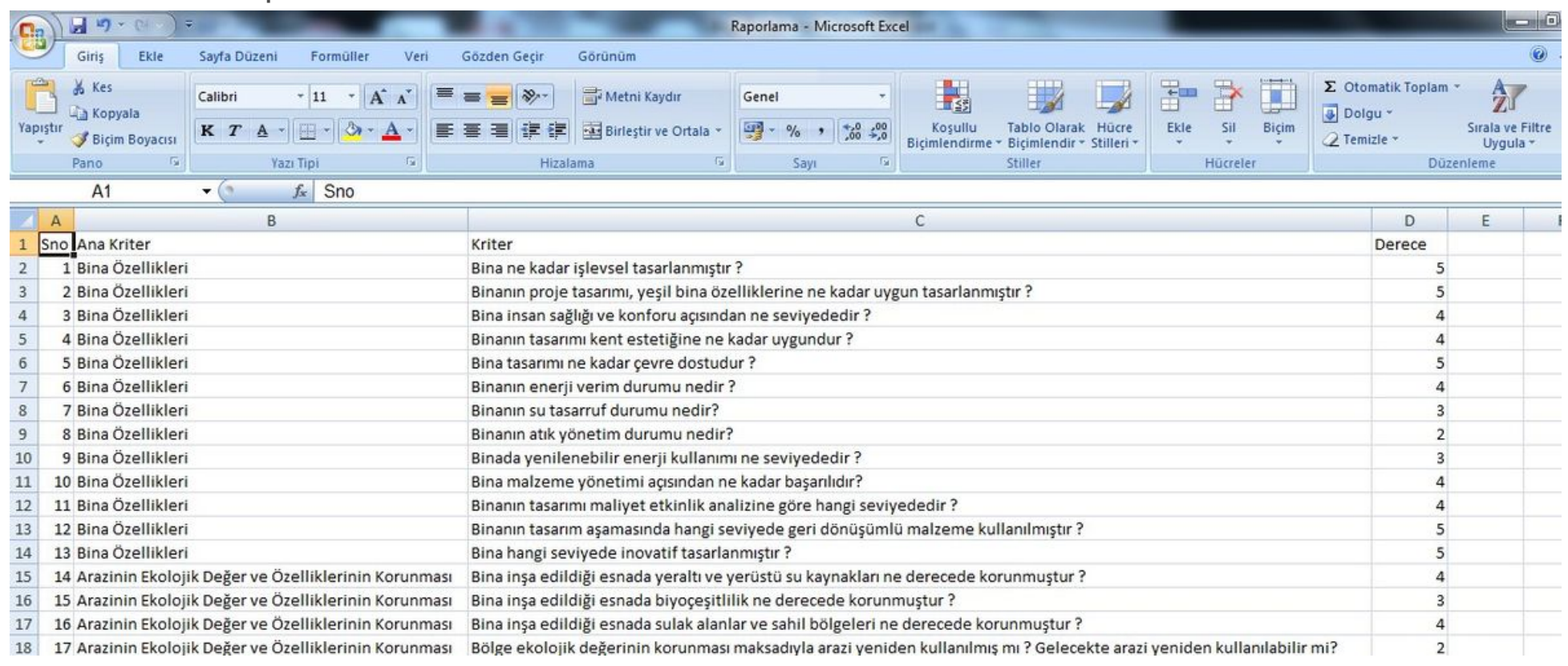

\section{Figure 7}

\section{A sample value table that was transferred to Excel}

